\title{
Multilevel governance in community-based environmental management: a case study comparison from Latin America
}

\author{
Claudia Sattler $^{1}$, Barbara Schröter $^{1}$, Angela Meyer $^{2}$, Gregor Giersch $^{2}$, Claas Meyer $^{1}$ and Bettina Matzdorf $^{1}$
}

\begin{abstract}
We analyze four case studies from Latin America using the concept of multilevel governance to assess at what vertical and horizontal levels and in what roles various state, market, and civil society actors interact for successful community-based environmental management (CBEM). In particular, we address the problem of how a conflict over natural resources with high negative impacts on the livelihoods of the respective communities could be overcome by a governance change that resulted in a multilevel governance arrangement for CBEM. The analysis involves a mixed-methods approach that combines a variety of empirical methods in social research such as field visits, personal interviews, participant observations, and stakeholder workshops. To visualize results, we introduce two schemes to present the composition of the governance structures for cross-case comparison. The first scheme plots the different actors into an arrangement that shows their associations with different societal spheres and at which territorial scales they are primarily involved. The second scheme differentiates these actors based on their complementing governance roles. Active roles are attributed to actors who implement activities on the ground, whereas passive roles are assigned to actors who provide specific resources such as knowledge, funding, legislative framework, or others. All cases involved governance actors from more than one societal sphere who operate on at least three different territorial levels (local to international) and in distinct roles. Results show that multilevel governance can strengthen CBEM in different ways. First, the success of CBEM is an outcome of the sum of horizontal and vertical interactions of all involved actors, and there is no most appropriate single level of social organization at which a problem can best be addressed. Only the cooperation of actors from different societal spheres within and across levels ensures accessibility to needed resources and implementation on the ground. Second, civil society actors seem to be crucial actors because they often function as the initiators of governance change and as bridging actors who connect other actors across levels. Third, to enable cross-scale interaction for improved decision making, often new actors are formed whose roles are wilfully negotiated. Fourth, despite different interests of actors, all multilevel governance arrangements for CBEM were able to provide benefits to all actors. Finally, in all cases, procedures for conflict resolution among parties are in place to address problems and allow for polycentric mutual decision making. Nevertheless, in view of transferability of the analyzed multilevel governance arrangements for CBEM, it is important to acknowledge that the differentiation in the cooperation of actors characterizes complex solutions that work for a specific context and that cannot be transferred directly to another context.
\end{abstract}

Key Words: civil society; community management; ecosystem services; environmental governance; intermediaries; natural resource management

\section{INTRODUCTION}

The following three concepts in governance are typically differentiated: hierarchies, markets, and community management (Vatn 2010). Hierarchical approaches are based on systems of command in which resource allocation occurs through existing authority and power structures. Market-based approaches are driven by the voluntary exchange of goods and services among individual actors, and resource allocation occurs based on willingness to pay. Finally, community management, which is the focus of this study, is based on cooperation among actors, and both individual and common goals are taken into account for resource allocation. In practice, hybrids of these approaches are common, which is also true for governance approaches in community management that typically hold elements of the other two concepts. For instance, comanagement arrangements involve both state and community actors, whereas community-developed payments for ecosystem services combine community management with market-based approaches.

Because of their hybrid character, many community-based approaches have evolved in a multilayered context. Multilevel governance (MLG) refers to the cooperation of different governance actors from different levels, where levels are understood to stretch potentially from the local and regional to the national and international scales. MLG contains both horizontal and vertical dimensions, and actors can cooperate not only within the same level but also across different territorial, administrative, and jurisdictional scales (Berkes 2006, Cash et al. 2006; O. R. Young, unpublished manuscript: http://dlc.dlib. indiana.edu/dlc/bitstream/handle/10535/519/youngo041300.pdf? sequence=1). Although MLG includes state actors as well as nonstate actors (as opposed to government, which is restricted to state actors), in recent years, the growing role of nonstate actors from the private and civil society sectors has been recognized (Bache and Flinders 2004). MLG can emerge from bottom-up as a result of voluntary collective action and bargaining or as a result of top-down mandated processes that strategically aim for more participation (Paavola 2008). Overall, MLG is understood as the outcome of a process of devolution and decentralization and of the upward, downward, and sideways reassignment of authority and responsibility among actors (Bache and Flinders 2004, Marks and Hooghe 2004).

Critiques of purely hierarchical top-down command and control or market-driven approaches are well established and have called for more adaptive and multilayered forms of governance (e.g.,

${ }^{1}$ Leibniz-Centre for Agricultural Landscape Research (ZALF), Institute of Socio-Economics, ${ }^{2}$ Organisation for International Dialogue and Conflict Management 
Folke et al. 2005, Vatn 2005, Armitage et al. 2007, Pahl-Wostl 2009). For instance, arguments for promoting MLG are based on increased participation and collaboration of diverse actors with different skills and resources (e.g., Bache and Flinders 2004, Kluvánková-Oravská et al. 2009, Newig and Fritsch 2009), improved accountability (e.g., Armitage 2007), better leadership and self-organization (e.g., Ostrom 1990, Folke et al. 2005), knowledge pluralism (e.g., Pellizzoni 2003, Newig and Fritsch 2009), mutual learning effects (e.g., Ernstson et al. 2010), more holistic problem understanding (Stern 2005), trust building (e.g., Folke et al. 2005), network creation (e.g., Armitage 2007), and greater acceptance of governance outcomes (see Newig and Fritsch 2009), which are all linked positively to improved decision making in governance (e.g., Armitage 2007, Newig and Fritsch 2009). In terms of decision making, MLG stands out because of its polycentricity with several decision points across governance levels. As a consequence, MLG allows for level-dependent interventions that often yield better decisions than monocentric governance (Dietz et al. 2003, Armitage 2007, Newig and Fritsch 2009; O. R. Young, unpublished manuscript: http://dlc.dlib. indiana.edu/dlc/bitstream/handle/10535/519/youngo041300.pdf? sequence=1). Because governance problems appear at different spatial scales that typically cut across and transcend established administrative and jurisdictional boundaries, MLG can also improve the institutional fit of governance solutions (Young 2002). Nevertheless, MLG arrangements can lead to their own problems. Because of the high number of actors involved, coordinating actors can become problematic, and too many decision points can hamper effective governance (Newig and Fritsch 2009).

In practice, MLG has been promoted as advisable for all scenarios that require integrated and concerted action at multiple levels within the spheres of policy, economy, and civil society (e.g., Pritchard and Sanderson 2002, Cash et al. 2006, Ernstson et al. 2010). Such promotion is particularly relevant for problems related to environmental governance and, in particular, ecosystem services provisioning, because these problems are frequently characterized by the features of common-pool resource management in which the costs of action are concentrated at the local level, whereas the benefits accrue at the global level (Ostrom 1990, Schreurs 2010).

Against this backdrop, we analyzed MLG in the context of community-based environmental management (CBEM), which is also referred to as community-based natural resource management as a specific type of community management. The CBEM literature emphasizes the role of local communities in inducing change in environmental governance to support ecosystem services provisioning and to promote local livelihoods (e.g., Agrawal and Gibson 1999, Berkes 2006, Cox et al. 2010, Gruber 2010, Liu et al. 2014). However, because of the hybrid nature of many CBEM approaches, it is also acknowledged that these approaches involve governance actors not only from the local community level but also from upper levels (Berkes and Seixas 2004, Paavola 2008, Gruber 2010, Seixas and Berkes 2010). Thus, CBEM approaches can differ widely with respect to the composition of their participants because different governance functions can be performed by different actors from different societal spheres and at different levels (Paavola 2008, Pahl-Wostl 2009, Schröter et al. 2014). A specific feature of CBEM is the twin objective of combining conservation efforts and protecting natural resources while achieving livelihood improvements for community members. In addition, although MLG in general has become a popular subject of research, in the context of environmental governance, this research has been given only scant attention (Paavola 2008). Instead, research in environmental governance has sought to determine the level of governance (local, regional, national, or international) at which it is best to respond to a given environmental problem (e.g., Young 2002, Luthe and Wyss 2016). Thus, to address this research gap, we explicitly focused on how MLG contributes to successful CBEM approaches by examining the actors involved from all levels. Therefore, our study aims to deepen the understanding of how the multilevel interaction of governance actors from different societal spheres can contribute to achieving the twin objectives of CBEM.

The analysis was based on the in-depth and comparative studies of four CBEM cases from Latin America. In all four cases, a conflict over natural resources with high negative effects on the livelihoods of the respective communities initiated a governance change that finally resulted in an MLG arrangement for CBEM. In particular, we investigated the following two research questions: (1) Who are the individual actors involved in CBEM and to which societal sphere and governance level are they assigned? (2) In what roles do actors from different societal spheres interact to promote CBEM, both horizontally within the same level and vertically across different governance levels?

For the first question, we focused on individual actors and their attributes, i.e., their association with societal spheres and their position at different governance levels. For the second question, we addressed the actors' relational aspects, i.e., in what roles actors interact vertically and horizontally and how this relates to their affiliations in different societal spheres and at different governance levels. Thereby, a particular focus is given to the analysis if the performed roles are more active (i.e., related to CBEM implementation) or passive (i.e., related to the provision of specific resources, such as funding, knowledge, etc.) to help achieve the twin objectives of CBEM.

\section{METHODS}

\section{Selection of case studies}

We chose four case studies from Latin America (Table 1), with the geographical focus being predefined by our funding scheme. The cases selected from Brazil and Costa Rica vary broadly in terms of their political, institutional, socioeconomic, and ecological framework conditions, but a mutual criterion for their selection was the presence of a successful CBEM approach. Successful, in this context, means that both objectives of CBEM were reached, i.e., improved conservation of natural resources and improved livelihoods for community members. Therefore, the communities themselves defined the success criteria. The cases represent a variety of different environmental problems always closely connected to livelihood issues, for which the communities eventually found successful solutions in the form of a multilayered governance change.

Many CBEM approaches constitute hybrid forms of governance that combine community management with elements of hierarchies and markets. Based on the three basic governance 
Table 1. Key characteristics of the selected case studies.

\begin{tabular}{|c|c|c|c|c|}
\hline \multirow[b]{2}{*}{$\begin{array}{l}\text { Characte- } \\
\text { ristic }\end{array}$} & \multicolumn{4}{|c|}{ Case study } \\
\hline & Marujá, Brazil & Santa Catarina, Brazil & Tocantins, Brazil & Osa, Costa Rica \\
\hline Location & $\begin{array}{l}\text { Within a designated area: } \\
\text { Cardoso Island State Park }\end{array}$ & $\begin{array}{l}\text { In the Encostas da Serra } \\
\text { Geral region (Santa Rosa de } \\
\text { Lima community) }\end{array}$ & $\begin{array}{l}\text { Central Brazil (Pium and other } \\
\text { communities) }\end{array}$ & In the Osa Conservation Area \\
\hline $\begin{array}{l}\text { Basis of } \\
\text { community } \\
\text { livelihoods }\end{array}$ & $\begin{array}{l}\text { Tourism, fishery, some art and } \\
\text { craft making }\end{array}$ & $\begin{array}{l}\text { Agriculture on mainly family- } \\
\text { owned, small-scale farms; } \\
\text { milk production from grazing } \\
\text { cattle is one of the most } \\
\text { predominant agricultural } \\
\text { activities }\end{array}$ & $\begin{array}{l}\text { Agricultural, as well as charcoal and oil } \\
\text { extraction from palm trees or } \\
\text { employment in the service and } \\
\text { industrial sector such as local ceramic } \\
\text { industries }\end{array}$ & Income from sea tourism \\
\hline $\begin{array}{l}\text { Relevant } \\
\text { ecosystems }\end{array}$ & $\begin{array}{l}\text { Atlantic rainforests with estuary- } \\
\text { lagoons, rivers, and mangrove } \\
\text { areas on one side of the island } \\
\text { and beaches and rocky coasts on } \\
\text { the other side }\end{array}$ & $\begin{array}{l}\text { Atlantic rain forests } \\
\text { embedded with partially very } \\
\text { steep grassland ecosystems }\end{array}$ & $\begin{array}{l}\text { Amazon forests, Pantanal wetlands, } \\
\text { cerrado savannas }\end{array}$ & $\begin{array}{l}\text { The largest remaining } \\
\text { reserves of mangroves and } \\
\text { other wetland areas on the } \\
\text { Pacific coast of Central } \\
\text { America }\end{array}$ \\
\hline $\begin{array}{l}\text { Causes of } \\
\text { threats } \\
\text { that } \\
\text { initiated } \\
\text { governance } \\
\text { change }\end{array}$ & $\begin{array}{l}\text { Uncontrolled construction } \\
\text { development because of mass } \\
\text { tourism and migration to the } \\
\text { region; because the state park } \\
\text { category does not allow } \\
\text { inhabitants inside the park, } \\
\text { relocation of existing } \\
\text { communities was planned }\end{array}$ & $\begin{array}{l}\text { Agricultural activities that } \\
\text { increased water pollution, soil } \\
\text { degradation, and native forest } \\
\text { destruction, making cattle } \\
\text { grazing less productive; these } \\
\text { problems were caused by } \\
\text { common grazing practices } \\
\text { that were very area } \\
\text { demanding with free-roaming } \\
\text { livestock }\end{array}$ & $\begin{array}{l}\text { Conversion of all three types of } \\
\text { ecosystems to pastureland to sustain } \\
\text { more cattle, infrastructure } \\
\text { development, and logging for timber; in } \\
2003,92 \% \text { of Tocantins' ceramic } \\
\text { industries burned timber as their main } \\
\text { fuel, which implied a high consumption } \\
\text { of native wood contributing to } \\
\text { deforestation; environmental effects } \\
\text { include biodiversity loss and release of } \\
\text { greenhouse gases }\end{array}$ & $\begin{array}{l}\text { Pressure from infrastructure } \\
\text { development for tourism such } \\
\text { as the construction of hotels } \\
\text { and roads (an airport and a } \\
\text { marina were planned); } \\
\text { despite their legal protection } \\
\text { status, wetlands are not } \\
\text { adequately conserved and } \\
\text { managed }\end{array}$ \\
\hline $\begin{array}{l}\text { Characte- } \\
\text { ristics of } \\
\text { governance } \\
\text { change }\end{array}$ & $\begin{array}{l}\text { Comanagement agreement } \\
\text { between the community and state } \\
\text { park. The community was } \\
\text { granted the right to stay in the } \\
\text { park as long as it respects the } \\
\text { rules laid out in an environmental } \\
\text { management plan restricting } \\
\text { economic activities and overall } \\
\text { tourist numbers. The rules allow } \\
\text { people to sustain their livelihoods } \\
\text { based on small-scale ecotourism } \\
\text { and fishing for self-consumption. } \\
\text { The community also agreed to } \\
\text { perform monitoring activities for } \\
\text { the state park. To achieve this, the } \\
\text { community self-organized and } \\
\text { founded an association through } \\
\text { which it could also participate in } \\
\text { rule negotiation }\end{array}$ & $\begin{array}{l}\text { Introduction of the so-called } \\
\text { Voisin system, which divides } \\
\text { grassland into paddocks for } \\
\text { improved grassland } \\
\text { management and is associated } \\
\text { with several environmental } \\
\text { benefits. Better cover of soil } \\
\text { improves soil organic matter } \\
\text { content and prevents run-off } \\
\text { and water erosion on the steep } \\
\text { lands. Because grazing } \\
\text { animals are fenced off from } \\
\text { surface waters, water quality is } \\
\text { improved. Through improved } \\
\text { management, the same area of } \\
\text { grassland now supports more } \\
\text { animals and improves the } \\
\text { livelihoods of local } \\
\text { community farmers }\end{array}$ & $\begin{array}{l}\text { Initially, a change in the energy source } \\
\text { used in ceramic industries from native } \\
\text { wood to rice husk as an unused waste } \\
\text { product. Main reasons for the change } \\
\text { were difficulties in acquiring timber } \\
\text { legally, pressure from clients for more } \\
\text { sustainable production, and fear of } \\
\text { image loss if the use of illegal timber } \\
\text { was discovered. Subsequently, the } \\
\text { Socialcarbon® standard was } \\
\text { introduced by the ceramic industries, } \\
\text { which generates carbon credits for } \\
\text { voluntary carbon markets. Attached to } \\
\text { the credits is an added social premium } \\
\text { for additional socioeconomic, technical, } \\
\text { and environmental improvements in the } \\
\text { factories to the benefit of local } \\
\text { employees. Improvements are assessed } \\
\text { in a participatory manner by } \\
\text { community members }\end{array}$ & $\begin{array}{l}\text { A combination of two } \\
\text { approaches: creation of a } \\
\text { corporate-funded payment } \\
\text { for ecosystem services for } \\
\text { carbon sequestration and } \\
\text { increasing environmental } \\
\text { awareness through } \\
\text { community-based mangrove } \\
\text { conservation activities, e.g., } \\
\text { building a community } \\
\text { nursery and mangrove } \\
\text { reforestation. Because } \\
\text { community members are paid } \\
\text { for these activities, the } \\
\text { additional income also } \\
\text { improves their livelihoods }\end{array}$ \\
\hline
\end{tabular}

concepts (see Vatn 2010), four possible hybrids can result due to overlaps between concepts. In our selection of cases, each case resembles one of the possible forms, thus covering all possible CBEM variations and always involving actors from different societal spheres (Fig. 1).

The community of Marujá, Brazil constitutes a comanagement agreement in which local resource users and government actors share power and responsibility in resource management (see Carlsson and Berkes 2005). In the communities of Tocantins, Brazil and Osa, Costa Rica, there is close cooperation between community and private actors, with both communities being involved in a market-based scheme of payment for ecosystem services (Sattler and Matzdorf 2013, Matzdorf et al. 2014). However, unlike in Tocantinsas, Osa contains several conservation areas, so public actors are also naturally engaged in that community. Finally, the community of Santa Catarina, Brazil is an example of an induced technology transfer (e.g., Chambers et al. 1989) encouraged by a civil society actor.

\section{Data collection and analysis}

Most information used in the analysis was collected during a sixweek field visit to the four selected case study communities in January and February 2012. During these visits, data were collected and later analyzed by employing a mixed-method approach that was based on empirical social research that engaged 
stakeholders on different scales (Diekmann 2001, Scholz and Tietje 2002). Stakeholders were thereby defined in line with Freeman (1984), i.e., as those who affect or are affected by a decision or action, in our cases, by decisions in the context of various CBEM arrangements.

Fig. 1. Representation of community-based environmental management approaches taken in the case studies (one pure and three hybrid forms).

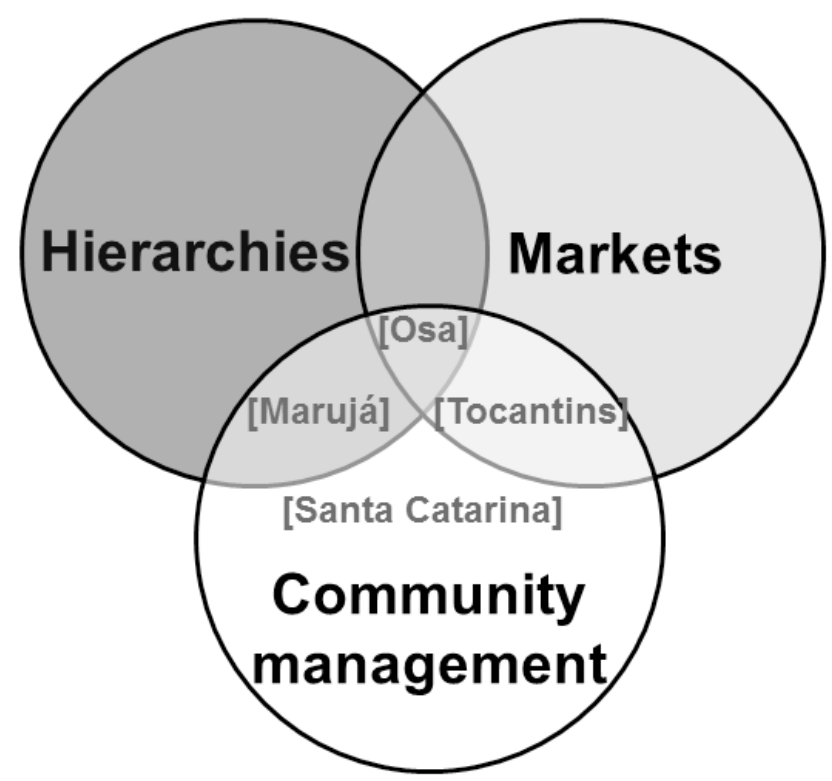

For our primary data collection, we used personal interviews, participant observations, stakeholder workshops with group discussions (see Lamnek and Krell 2010), and participatory videos (see Lunch and Lunch 2006). Further secondary data sources, including reports, government documentation, and websites, were also inventoried. For data analysis, we primarily used written materials such as interview transcripts, workshop minutes, and handwritten notes from participant observations, for content analysis (see Mayring 2008). In some cases, we also went back to analyzing the original footage or audio recordings for verification purposes. The triangulation method was also used to address discrepancies in analyzed statements and to facilitate validation of researched patterns by means of cross-verification from different data sources (see Flick 2004; Table 2).

To visualize the results for our first research question (Fig. 2), we introduced a graph in which the horizontal dimension of MLG (i.e., actors engaged at the same governance level) is linked to the $\mathrm{x}$-axis, and the vertical dimension of MLG (i.e., actors engaged across different governance scales) in CBEM is linked to the yaxis. State (government or public), market (corporate or private), civil society (nonprofit), and cross-sectoral (e.g., public or private research institutes) actors were color-coded and plotted along these dimensions to indicate their vertical and horizontal levels of governance. The information used for their placement was based on information retrieved from the analyzed original data. In most cases, placement was straightforward, and a clear assignment to one level could be made. In other cases, placement was ambiguous because some actors perform activities at several levels; for example, one interviewee from a nongovernmental organization (NGO) stated he/she acted primarily at the national level but also sustained regional field stations. In such cases, the actors were placed between the respective levels. The term "community actors" is used to refer to those actors that are associated with the local scale. Community actors can include actors from all societal sectors.

To visualize the results for our second research question (Fig. 3), we used a similar graph, but with the $\mathrm{x}$-axis indicating the role in which the actors were primarily engaged. Therefore, we differentiated between more active and more passive roles. Active roles were attributed to actors who function as implementers and who perform on-the-ground activities within CBEM. Passive roles were attributed to actors who function as providers of specific resources (e.g., knowledge, funding, legislative framework). Actors were placed along the gradient based on their avowed prior roles. Actors placed in the middle engage in both roles. We retained the information on actors' level of engagement in MLG on the y-axis and the color code showing the societal sphere to which the actors belong.

Overall, we followed an inductive approach, moving from specific observations in the single case studies to broader generalizations based on observed commonalities.

\section{RESULTS}

Individual actors involved in community-based environmental management, their assigned societal spheres, and level of engagement

To address our first research question, we focused on the analysis of individual actors. In particular, we examined their association with various societal spheres (state, market, and civil society) and their level of engagement in CBEM governance (local, regional, national, and international). For brevity, we use abbreviations to refer to various actors in both the text and figures (see Table 3).

\section{Actors in Marujá}

The CBEM governance model in Marujá involves four levels that span from local to international (Fig. 2A). AMOMAR is a civil society actor representing the entire Marujá community. It was founded to promote self-organization and collective action in the community and has three basic aims: to fight for the rights of traditional Marujá residents to remain in the state park, to secure their quality of life, and to conserve the natural resources they depend on for their livelihoods. EMON are market actors who work as freelancers for the Cardoso Island State Park (PEIC). The only actor situated at the regional level is the park council (PCOU), which consists of representatives of all types of actors and is thus classified as cross-sectoral. Three public actors (PEIC, EPOL/PGUA, and FF/SE) are in charge of the park management and are located at the regional to national levels. Visiting tourists (TOU) are mostly from the region or from other parts of Brazil (there are few international visitors) and are thus placed between the regional and national levels. Finally, KFW provided external funds to develop the management plan through the Atlantic Forest Protection Program (PPMA).

\section{Actors in Santa Catarina}

The CBEM approach in Santa Catarina involves four levels: local, regional, national, and international (Fig. 2B). Local community actors include family farmers (FARM). Dairy houses (DAIR) for 
Fig. 2. Actors' associations with societal sectors and level of governance engagement in each case study. (A) Marujá, (B) Santa Catarina, (C) Tocantins, (D) Osa. White = civil society (nonprofit) actors, light gray = market (corporate or private) actors, dark gray $=$ state (government or public) actors, and black $=$ cross-sectoral actors (e.g., research institutes or governance actors engaged in more than one sector).
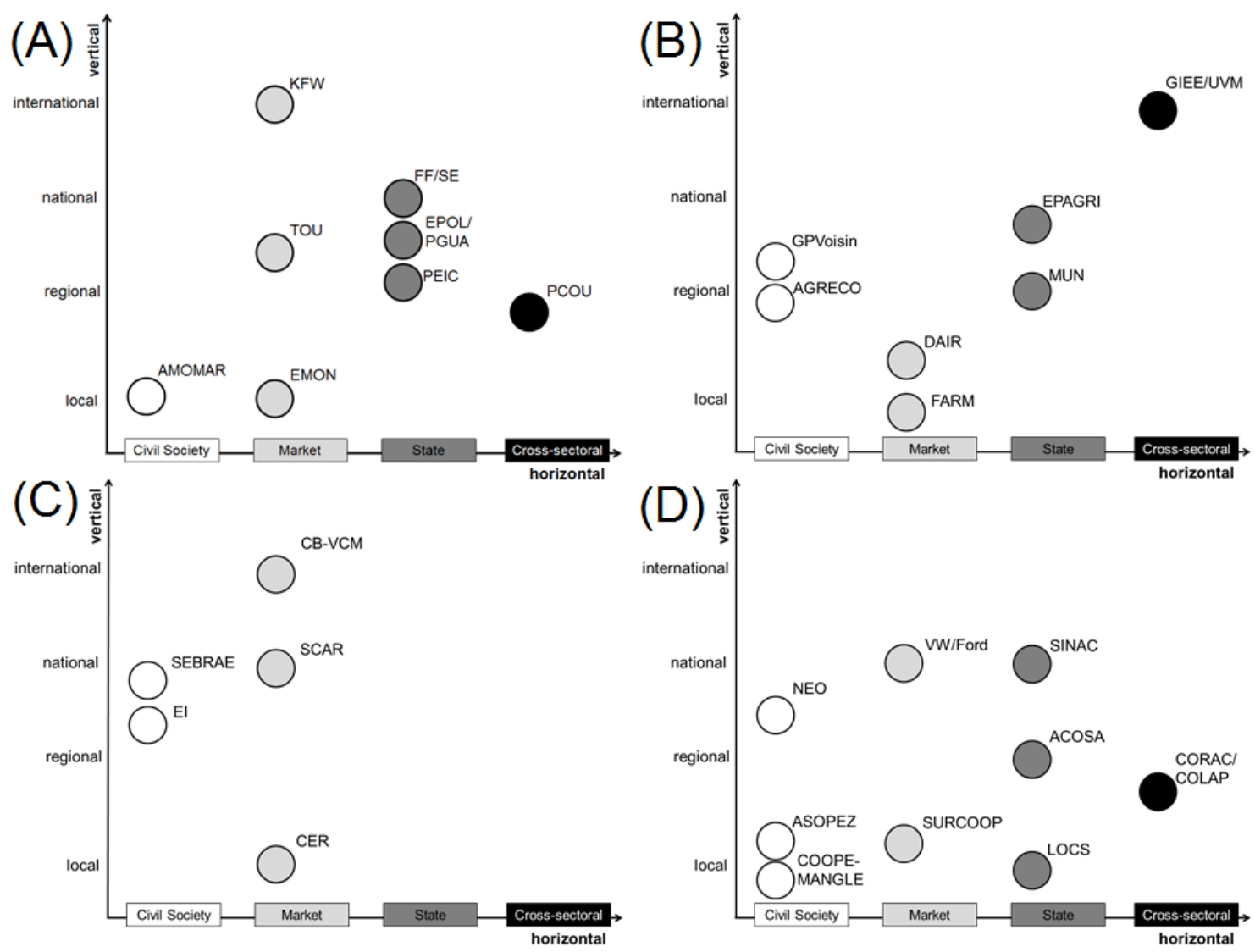

milk processing are based locally but are also engaged in regional marketing activities and are thus placed between the local and regional levels. Both FARM and DAIR are for-profit actors. Three actors are located at the regional level: AGRECO, GPVoisin, and the Municipality of Santa Rosa de Lima (MUN). AGRECO is an NGO dedicated to promoting sustainable and organic farming in the region. GPVoisin is a civil society actor linked to the Federal University of Santa Catarina and comprising a loose group of students and university staff members who are determined to spread the Voisin system to farmers in the region. Membership in the group is voluntary. MUN is a public actor at the regional level. National actor EPAGRI is the federal extension service of the state, which offers free advice to farmers and promotes the introduction of the Voisin system, mainly because of its economic benefits. GIEE/UVM, an international actor from USA, is connected to the CBEM approach through a GPVoisin member; it has cooperated with GPVoisin in several research projects on the Voisin system.

\section{Actors in Tocantins}

The CBEM approach in Tocantins involves four levels: local, regional, national, and international (Fig. 2C). The local community level involves several ceramic plants (CER) as market actors who have switched their energy source from native wood to rice husks. This process was supported by a national Brazilian NGO (EI) that also engages regionally and has a mission of climate change mitigation through research, conservation, and community management activities. EI developed the Socialcarbon ${ }^{\circledR}$ standard used in the CBEM approach. SEBRAE is a national NGO that aims to stimulate entrepreneurship and the competitiveness of smaller enterprises by means of capacitation. SCAR is a national for-profit actor accredited by EI to use the Socialcarbon ${ }^{\circledR}$ standard in carbon offset projects. SCAR also acts as the main seller of the generated credits to the final actor at the international level: credit buyers in the voluntary carbon market (CB-VCM).

\section{Actors in Osa}

CBEM in Osa involves three levels: local, regional, and national (Fig. 2D). ASOPEZ is an NGO founded by the fishermen in the community that promotes environmentally friendly fishing practices. COOPEMANGLE is an NGO founded by mangrove workers and was a conservation pioneer in the region; it currently offers ecotourism activities and education services. SURCOOP is a for-profit organization of agricultural workers seeking to improve farmers' economic livelihoods through sustainable 
Table 2. Research methods used and their application in each case study.

\begin{tabular}{|c|c|c|c|c|c|}
\hline \multirow[t]{2}{*}{ Method } & \multirow[t]{2}{*}{ Description of method } & \multicolumn{4}{|c|}{ Application of method } \\
\hline & & $\begin{array}{c}\text { Marujá } \\
\text { (18-26 January } \\
\text { 2012) } \\
\end{array}$ & $\begin{array}{c}\text { Santa Catarina } \\
(6-11 \text { February } \\
2012) \\
\end{array}$ & $\begin{array}{c}\text { Tocantins } \\
\text { (27 January-5 } \\
\text { February 2012) } \\
\end{array}$ & $\begin{array}{c}\text { Osa } \\
(14-24 \text { February 2012) }\end{array}$ \\
\hline $\begin{array}{l}\text { Personal } \\
\text { interviews }\end{array}$ & $\begin{array}{l}\text { Semistructured, face-to-face interviews, based on } \\
\text { interview guidelines; contained mostly open- } \\
\text { ended questions asking about relevant actors, } \\
\text { their interactions, actors' roles, existing problems } \\
\text { and how they were addressed, etc.; interviews } \\
\text { were audio-recorded }\end{array}$ & $\begin{array}{l}20 \text { interviews } \\
\text { with } \\
\text { community } \\
\text { members, } \\
\text { members of the } \\
\text { community } \\
\text { association, } \\
\text { state park } \\
\text { employees, } \\
\text { scientists }\end{array}$ & $\begin{array}{c}16 \text { interviews } \\
\text { with community } \\
\text { farmers, } \\
\text { employees from } \\
\text { extension } \\
\text { services, } \\
\text { nongovernmental } \\
\text { organizations, } \\
\text { dairy houses, } \\
\text { scientists }\end{array}$ & $\begin{array}{c}19 \text { interviews with } \\
\text { community members, } \\
\text { employees and } \\
\text { directors of two } \\
\text { ceramic industries, } \\
\text { employees of a rice } \\
\text { mill, } \\
\text { nongovernmental } \\
\text { organizations, } \\
\text { minister for the } \\
\text { environment, } \\
\text { indigenous group } \\
\text { representatives }\end{array}$ & $\begin{array}{l}24 \text { interviews with } \\
\text { community members, } \\
\text { mayor, members of } \\
\text { fishers association, } \\
\text { nongovernmental } \\
\text { organizations, school } \\
\text { teachers, girl and boy } \\
\text { scouts, director of a } \\
\text { conservation area, } \\
\text { minister for the } \\
\text { environment, tourist } \\
\text { guides }\end{array}$ \\
\hline $\begin{array}{l}\text { Participant } \\
\text { observations }\end{array}$ & $\begin{array}{l}\text { Observers accompanied stakeholders in their } \\
\text { daily life activities and also sat in on meetings; } \\
\text { documentation was by handwritten notes, } \\
\text { sometimes audio-recording }\end{array}$ & $\begin{array}{l}\text { Activities } \\
\text { included } \\
\text { garbage } \\
\text { management, } \\
\text { waste water } \\
\text { treatment, } \\
\text { fishing, net } \\
\text { mending, meal } \\
\text { preparation }\end{array}$ & $\begin{array}{l}\text { Activities } \\
\text { included } \\
\text { livestock tending, } \\
\text { planning tree } \\
\text { clusters in } \\
\text { paddocks for } \\
\text { shading }\end{array}$ & $\begin{array}{l}\text { Activities included } \\
\text { ceramic factory work } \\
\text { such as loading ovens } \\
\text { with rice husk, } \\
\text { pressing and baking } \\
\text { bricks and tiles }\end{array}$ & $\begin{array}{l}\text { Activities included } \\
\text { work in the mangrove } \\
\text { nursery, work with } \\
\text { children for } \\
\text { environmental } \\
\text { education }\end{array}$ \\
\hline $\begin{array}{l}\text { Stakeholder } \\
\text { workshops }\end{array}$ & $\begin{array}{l}\text { Workshops with } 12-40 \text { participants were held to } \\
\text { inform them about the project, ask for } \\
\text { involvement, collect opinions, and let } \\
\text { participants discuss certain topics; workshops } \\
\text { were audio-recorded and handwritten notes were } \\
\text { taken; minutes and presentations were archived }\end{array}$ & $\begin{array}{l}1 \text { workshop } \\
\text { (24 January) } \\
26 \text { participants }\end{array}$ & $\begin{array}{l}1 \text { workshop } \\
\text { (10 February) } \\
40 \text { participants }\end{array}$ & $\begin{array}{l}1 \text { workshop } \\
\text { (1 February) } \\
28 \text { participants }\end{array}$ & $\begin{array}{l}2 \text { workshops } \\
\text { (17 and } 18 \text { February) } \\
12 \text { and } 26 \text { participants, } \\
\text { respectively }\end{array}$ \\
\hline $\begin{array}{l}\text { Participatory } \\
\text { videos }^{\dagger}\end{array}$ & $\begin{array}{l}\text { Community stakeholders were actively involved } \\
\text { in video production; the project team facilitated } \\
\text { by teaching participants how to use the filming } \\
\text { equipment; footage was selected at daily } \\
\text { screenings; English subtitles were added at } \\
\text { postproduction }\end{array}$ & 1 video & none & 1 video & 1 video \\
\hline $\begin{array}{l}\text { Collection of } \\
\text { secondary } \\
\text { data }\end{array}$ & Collected and archived for further analysis & \multirow{2}{*}{\multicolumn{4}{|c|}{$\begin{array}{c}\text { For all case studies: environmental management plans of conservation units, } \\
\text { environmental laws and regulations, reports of previous research projects, existing } \\
\text { theses and dissertations (bachelors, masters, and doctoral), peer-reviewed articles, } \\
\text { materials collated from websites, minutes and other materials } \\
\text { For all case studies: analysis of available materials (written, audio, and video) }\end{array}$}} \\
\hline $\begin{array}{l}\text { Content } \\
\text { analysis }\end{array}$ & $\begin{array}{l}\text { MAXQDA software was used for interpretive } \\
\text { evaluation of collected primary and secondary } \\
\text { data; a system of categories was developed } \\
\text { (coded), e.g., actors, actors' attributes, and roles, } \\
\text { and the material was analyzed in-depth by } \\
\text { grouping statements according to the categories }\end{array}$ & & & & \\
\hline
\end{tabular}

agriculture. Local schools (LOCS) are another community actor that organized environmental clubs for wetland conservation; both teachers and pupils are involved in this project. Positioned at the regional level are ACOSA and CORAC/COLAP. ACOSA is one of the 11 conservation areas in Costa Rica in charge of the area's overall management. ACOSA established two councils, a regional council (CORAC) and three local (COLAP) councils, comprising representatives from public, private, and civil society sectors. NEO is an environmental NGO positioned between the national and regional levels; it is headquartered in San José but also maintains regional field stations. Its mission is to spur sustainable development by promoting community self- management. SINAC is a national actor responsible for establishing the conservation units in Costa Rica (including ACOSA) to manage the country's natural resources. Finally, Volkswagen AG and Ford Motor Company (VW/Ford) are the national offices of the international automobile manufacturers, which buy carbon credits generated by the CBEM approach to mangrove protection and reforestation.

Cross-case comparison of actors

All cases involve actors from more than one societal sphere, including cross-sectoral actors in three cases, i.e., Marujá, Santa Catarina, and Osa. In terms of governance levels (local to 
Fig. 3. Actors' roles in community-based environmental management interactions. (A) Marujá, (B) Santa Catarina, (C) Tocantins, (D) Osa. White $=$ civil society (nonprofit) actors, light gray = market (corporate or private) actors, dark gray $=$ state (government or public) actors, and black $=$ cross-sectoral actors (e.g., research institutes or governance actors engaged in more than one sector).
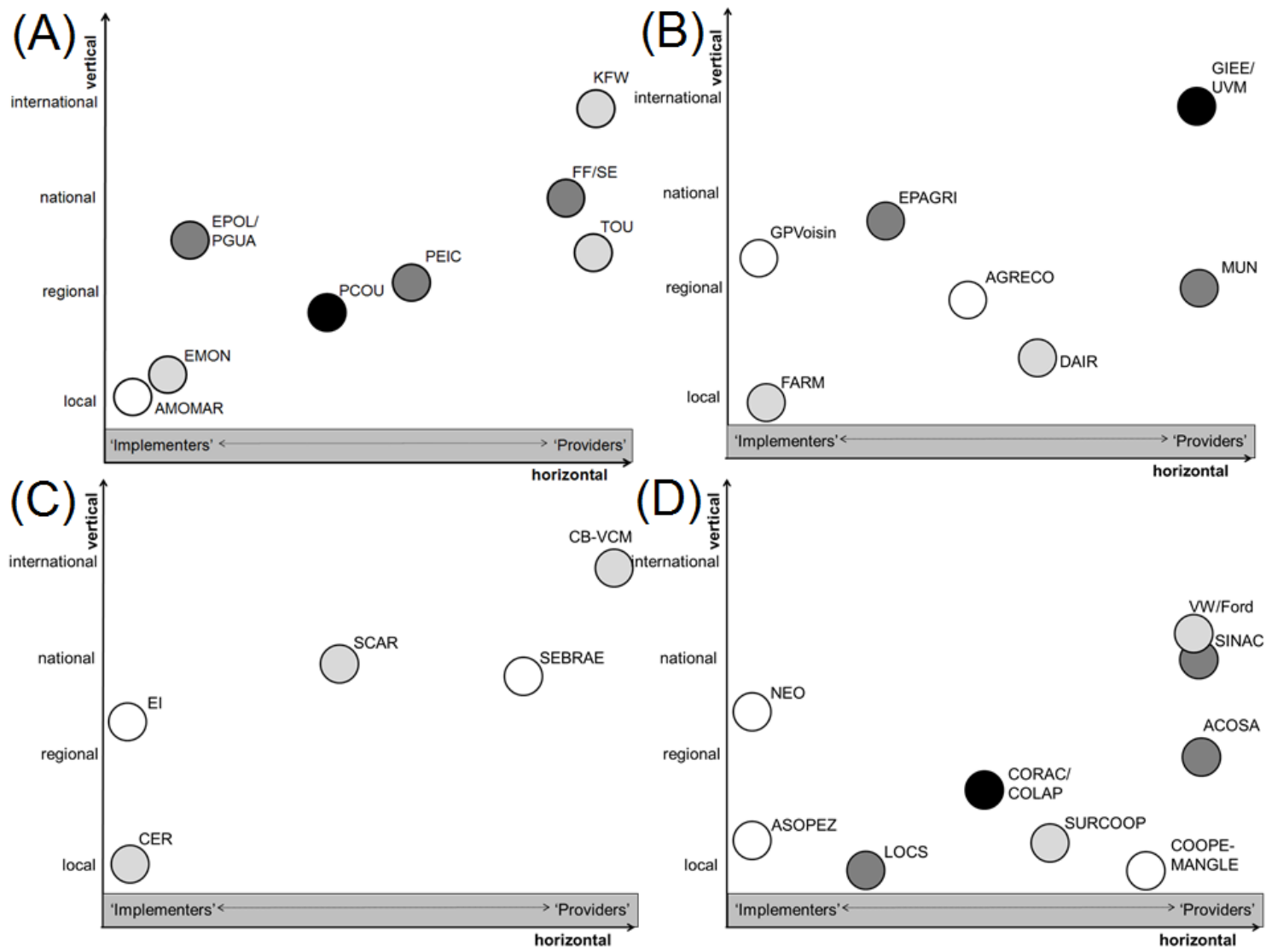

international), actors operate at least on three different territorial scales in all cases: local to national in Marujá and Osa, and local to international in Santa Catarina and Tocantins. By comparison, civil society actors (AMOMAR, GPVoisin, AGRECO, EI, COOPEMANGLE, ASOPEZ, NEO) are mostly involved locally to regionally, state actors mostly regionally to nationally (with the exception of LOCS), and cross-sectoral actors either regionally (PCOU a COLAP/CORAC) or internationally (GIEE/ UVM). In contrast, market actors from all levels are involved.

\section{Actors' roles in horizontal and vertical interactions in community-based environmental management based on their assigned societal spheres and level of engagement}

To address our second research question, we investigated the relational aspects of all the actors. In particular, we analyzed in what roles actors from the different sectors interact with one another to promote CBEM. More active roles are attributed to actors responsible for CBEM implementation activities; more passive roles are attributed to actors who function in provisioning of specific resources such as knowledge, external funding, or the legislative framework necessary to allow the CBEM approach to work (Fig. 3).
Actors' roles in Marujá

Active roles: AMOMAR is the key player in the self-organization of the community and functions as the main decision-making body (Fig. 3A). It was an active participant in developing the management plan for the state park and performs monitoring activities for the PEIC. EMON accompanies tourists for hiking and boating tours because tourists are not allowed to roam the park on their own. On these tours, guides provide environmental education and raise awareness regarding environmental issues. AMOMAR shares the task of monitoring the park with the park guards (PGUA) employed by the park. In severe cases of rule violations (e.g., illegal fishing, deforestation, palm heart harvesting, construction), EPOL is informed and is authorized to make arrests. The park council (PCOU) was newly created during the process of negotiating the management plan. Today, it is crucial in translating decisions between the national and local levels because the community must address all requests to the council and not directly to the PEIC. In this respect, the council functions like a bridge between the upper and lower levels.

Passive roles: PEIC is responsible for the overall management of the conservation area, but its headquarters is located outside the park. Thus, it provides infrastructure (e.g., a boat for patrolling) 
Table 3. Abbreviations, full names, and attribute data for all actors.

\begin{tabular}{|c|c|c|c|c|}
\hline Abbreviation & Full name & Sector & Level & Case study \\
\hline ACOSA & Conservation Area of Osa (Área de Conservación Osa) & State & Regional & Osa \\
\hline AGRECO & $\begin{array}{l}\text { Association of Organic Farmers of Encostas da Serra } \\
\text { (Associação dos Agricultores Ecológicos das Encostas da } \\
\text { Serra) }\end{array}$ & Civil & Regional & Santa Catarina \\
\hline AMOMAR & $\begin{array}{l}\text { Association of Traditional Marujá Residents (Associação } \\
\text { dos Moradores do Marujá) }\end{array}$ & Civil & Local & Marujá \\
\hline ASOPEZ & $\begin{array}{l}\text { Association of Fishermen in Golfo Dulce (Asociación de } \\
\text { Pescadores del Golfo Dulce) }\end{array}$ & Civil & Local & Osa \\
\hline CB-VCM & $\begin{array}{l}\text { Credit buyers on the voluntary carbon market (Compradores } \\
\text { de créditos no mercado de carbono voluntário) }\end{array}$ & Market & International & Tocantins \\
\hline CER & Ceramic industries (Cerâmicas) & Market & Local & Tocantins \\
\hline COOPEMANGLE & Mangrove Cooperative (Cooperación Mangle) & Civil & Local & Osa \\
\hline CORAC/COLAP & $\begin{array}{l}\text { Regional Council of ACOSA/Local Council of ACOSA } \\
\text { (Consejo Regional de ACOSA/Consejo Local de ACOSA) }\end{array}$ & $\begin{array}{l}\text { Cross- } \\
\text { sectoral }\end{array}$ & Regional-local & Osa \\
\hline DAIR & Dairy houses (Laticinio) & Market & Local-regional & Santa Catarina \\
\hline EI & Ecological institute (Instituto ecológica) & Civil & National-regional & Tocantins \\
\hline EMON & Environmental monitors (Monitores do ambiente) & Market & Local & Marujá \\
\hline EPAGRI & $\begin{array}{l}\text { Federal Extension Service of Santa Catarina (Empresa de } \\
\text { Pesquisa Agropecuária e Extensão Rural de Santa Catarina) }\end{array}$ & State & National-regional & Santa Catarina \\
\hline EPOL/PGUA & $\begin{array}{l}\text { Environmental police/park guards (Policia ambientallguarda } \\
\text { parques) }\end{array}$ & State & Regional & Marujá \\
\hline FARM & Family dairy famers (Agricultores familiars) & Market & Local & Santa Catarina \\
\hline $\mathrm{FF} / \mathrm{SE}$ & $\begin{array}{l}\text { Forest Foundation/Secretary of Environment (Secretaria do } \\
\text { Meio Ambiente) }\end{array}$ & State & National & Marujá \\
\hline GIEE/UVM & $\begin{array}{l}\text { Gund Institute for Ecological Economics/University of } \\
\text { Vermont }\end{array}$ & Cross-secoral & International & Santa Catarina \\
\hline GPVoisin & Voisin Group (Grupo Pastoreio Voisin) & Civil & Regional & Santa Catarina \\
\hline KFW & Bank (Kreditanstalt fuer Wiederaufbau) & Private & International & Marujá \\
\hline LOCS & Local schools (Escuelas locales) & State & Local & Osa \\
\hline MUN & $\begin{array}{l}\text { Municipality of Santa Rosa de Lima (Municipalidade de } \\
\text { Santa Rosa de Lima) }\end{array}$ & State & Regional & Santa Catarina \\
\hline NEO & Neotropica Foundation (Fundación Neotrópica) & Civil & Regional-national & Osa \\
\hline PCOU & Park Council (Conselho do Parque) & $\begin{array}{l}\text { Cross- } \\
\text { sectoral }\end{array}$ & Regional & Marujá \\
\hline PEIC & Cardoso Island State Park (Parque Estadual Ilha do Cardoso) & State & Regional-national & Marujá \\
\hline SCAR & Sustainable carbon & Market & National & Tocantins \\
\hline SEBRAE & $\begin{array}{l}\text { Micro and Small Enterprises' Support Service (Serviço de } \\
\text { Apoio às Micro e Pequenas Empresas) }\end{array}$ & Civil & National-regional & Tocantins \\
\hline SINAC & $\begin{array}{l}\text { National System of Conservation Units (Sistema Nacional } \\
\text { de Áreas de Conservación) }\end{array}$ & State & National & Osa \\
\hline SURCOOP & $\begin{array}{l}\text { Cooperative for Self-managed Production of Livestock and } \\
\text { Other Services in the South (Cooperativa Autogestionaria de } \\
\text { Producción Agropecuaria Industrial y de Servicios Múltiples } \\
\text { del Sur) }\end{array}$ & Market & Local-regional & Osa \\
\hline TOU & Visiting tourists (Turistas) & Market & International-national & Marujá \\
\hline VW/Ford & $\begin{array}{l}\text { Volkswagen AG/Ford Motor Company (Volkswagen } \\
\text { Automotriz S.A./Ford Nacional Automotriz NASA S.A.) }\end{array}$ & Market & National & Osa \\
\hline
\end{tabular}

and also financial resources (e.g., to hold park council meetings). FF and SE are based in the state capital and are responsible for managing all conservation units and providing the overall legislative framework. Finally, tourists (TOU) are short-term visitors to the region and provide the community with its main source of income. KFW provided additional funding for developing the management plan.

Actors' roles in Santa Catarina

Active roles: GPVoisin and dairy farms (FARM) implement the Voisin system together on the farms, which involves dividing the paddocks, putting up the fences, installing standpipes, and other activities (Fig. 3B). Together, they also organize field days and workshops for other interested farmers. For GPVoisin, most activities are based on unpaid voluntary work of students. Nonetheless, students are highly motivated because education at the university is theoretical, and their membership in GPVoisin offers them a chance for practical work. Relations between the students of GPVoisin and farmers are sometimes very close because students live with the farmers when installing the system. The extension service EPAGRI is involved in these activities (e. g., field days) and also offers technical advice. It is also common that farmers help one another when the system is installed.

Passive roles: AGRECO supports farmers aiming to make the transition from conventional to organic production, including 
services for organic product placing, advertisement, and marketing. AGRECO also successfully introduced a label for organic products in the region and offers capacity trainings (e.g., optimized production, waste reduction). Dairy houses (DAIR) provide services for further milk processing (e.g., cheese production). Farmers can chose between several competing dairy houses. The municipality (MUN) is mainly involved through infrastructure support. Because dairy farms are nested far from one another in the hilly landscape, a milk car collects the milk and thus depends on good road conditions. MUN improved several roads that were formerly dusty tracks. By cooperating in several continuing research projects with GIEE/UVM, GPVoisin received additional financial resources for its work.

\section{Actors' roles in Tocantins}

Active roles: EI, together with CER, implemented the Socialcarbon ${ }^{\circledR}$ standard in the ceramic factories, which involved choosing six indicators (carbon emissions reduction, social, human, financial, natural, and technological developments) to measure improvements in the factories toward sustainable development against a set baseline (Fig. 3C). If the overall situation improves based on the participatory assessment of the workers (e.g., improved health through fewer accidents in the factories), it translates into premiums additional to the price for the carbon credits.

Passive roles: SCAR verifies the carbon credits that are calculated based on the Verified Carbon Standard. SEBRAE offers additional support by providing capacitation and training services for the factories. Finally, CB-VCM generates financial returns for the factories by buying carbon credits.

\section{Actors' roles in $\mathrm{Osa}$}

Active roles: The fishers' association (ASOPEZ) performs the actual conservation activities in the region together with NEO (Fig. 3D). These activities include maintaining the nursery and planting mangroves in combination with environmental education measures. Pupils and students of LOCS actively participate in these activities on a purely voluntary basis.

Passive roles: CORAC/COLAP are cross-level decision-making bodies that reconcile local activities with administering the conservation unit ACOSA and SINAC. SURCOOP and COOPEMANGLE offer support mainly by providing knowledge regarding sustainable practices and mangrove protection. SURCOOP also offers training for capacity building. ACOSA and SINAC provide the legal framework for activities. In particular, SINAC is involved in the administration and implementation of key environmental laws. Finally, VW/Ford provides the main external funding for the CBEM approach.

\section{Cross-case comparison of actors' roles}

In terms of actors' roles based on their assigned societal spheres, comparing all four cases reveals no uniform pattern that suggests that actors from a certain societal sphere are primarily involved exclusively in either active or passive roles. In all cases, state, market, and civil society actors are involved in both roles. Nevertheless, for civil society actors, there is a clear tendency to assume more active roles. Altogether, five (AMOMAR, GPVoisin, EI, NEO, and ASOPEZ) of the eight civil society actors play active roles. In each case study, at least one civil society actor is actively involved. By contrast, state actors (e.g., FF/SE,
MUN, SINAC, and ACOSA) tend to hold more passive roles. For market and cross-sectoral actors, no clear picture emerges.

In terms of actors' level of engagement, two tendencies can be observed across cases. First, most locally involved actors (AMOMAR, EMON, FARM, CER, ASOPEZ, LOCS) assume active roles, which is to be expected in CBEM, whereas only a few local actors play more passive roles (SURCOOP, COOPEMANGLE). Second, international actors are all involved more passively (GIEE/UVM, CB-VCM). For regional and national actors, the pattern is less clear; they act in both roles of implementer and provider.

\section{DISCUSSION}

How do actors' horizontal and vertical interactions promote community-based environmental management?

Although MLG has the potential to improve environmental management (Ernstson et al. 2010), it does not produce enhanced governance per se (Vatn and Vedeld 2012). Instead, the quality of MLG interaction is decisive, i.e., how actors pool resources, complement one another in their roles, bridge goals, and plan and learn together (Vatn and Vedeld 2012).

For horizontal interactions in the four cases, the benefit for CBEM is based on each MLG actor contributing something essential (see Paavola 2008, Schreurs 2010, Van der Heijden 2011), which involves, for example, the initiative to encourage governance change in the first place (e.g., AMOMAR, GPVoisin, EI, NEO), the willingness to implement activities on the ground (e.g., EMON, EPOL/PGUA, LOC), or the provision of knowledge (e. g., AGRECO, SEBRAE, COOPEMANGLE), specific services (e.g., DAIR, MUN, SCAR, SURCOOP), or funding (e.g., KFW, GIEE/UVM, VW/Ford). In this manner, actors from the different societal spheres are predestined to provide different things and perform different roles (R. G. Strachwitz, unpublished presenation: http://cardiff.civiland-zalf.org/download/Rupert-Graf-Strachwitz. pdf). Public actors naturally are most suited to influence the legal setting so that there is sufficient leeway for governance change to occur (e.g., PEIC or ACOSA). Market actors can efficiently provide professional services that are required (e.g., certification by SCAR, product processing by DAIR). Finally, civil society actors, because they engage in purpose-driven and not-for-profit activities and have access to their own financial and human resources, seem most suited to function as the initiators of governance change (e.g., AMOMAR, GPVoisin, EI, or NEO).

For vertical interactions, the benefit for CBEM through MLG results from a better distribution of responsibilities in decisionmaking functions across levels (Vatn and Vedeld 2012). In the case studies, it required greater authority and power to be shifted toward local groups (e.g., toward the community foundation AMOMAR, or to the newly established councils PCOU, COLAP/ CORAC; see Agrawal and Gibson 1999). In this manner, a system of separate decisions (e.g., communities vs. PEIC in Marujá; each farmer for himself in Santa Catarina) was transformed into a system of mutual decisions (e.g., community cooperates through AMOMAR and PCOU with PEIC; farmers become connected to one another through GPVoisin). To this effect, former decision takers (e.g., the communities in Marujá and Osa) became actual decision makers (through their representation in PCOU or CORAC/COLAP). In turn, decisions made through the councils 
gained increased legitimacy and accountability in the eyes of the local population (see Cash et al. 2006). Altogether, introducing additional decision points allows for decisions to be made at the most appropriate level and with the participation of those stakeholders that also bear the consequences of those decisions (see Paavola 2008).

\section{How were links between actors created?}

Although local actors are crucial in providing the place-specific knowledge and for coordinating action within the community (Ernstson et al. 2010), they frequently lack the financial resources, organizational skills, and political power that can be provided better by larger and more influential national and international actors (Agrawal and Gibson 1999). This situation raises the question of how the links were created that now connect actors across and within different levels. In all cases, civil society actors played a vital role because they were the initiators of the governance change, and most links were established through them (e.g., AMOMAR reached out to the PEIC to start a dialogue; GPVoisin created the link to GIEE/UVM for additional funding; NEO and EI connected community actors with national and international credit buyers). Additionally, in three of the cases, the civil society actors (GPVoisin, EI, and NEO) are positioned between levels, which allows them to connect the actors from the lower and upper levels and helps enlarge the network of local actors using only limited resources and orient this network toward actors with greater resources (e.g., GIEE/UVM, CB-VCM, VW/ Ford). Thus, the links are not necessarily established directly between the community and actors at the national and international levels, but actors are instead connected indirectly through intermediate actors. Thus, reciprocity, which is often promoted as crucial in CBEM (e.g., Ostrom 1990), although important at the local and regional levels (e.g., between AMOMAR and EMON, FARM and DAIR, and ASOPEZ and LOCS), seems less important at the upper levels. Instead, establishing links in this case is driven by the functional relationship that results from the nature of the given problem (see Young 2002). For instance, for climate change issues in Tocantins and Osa, links between the local community members who engage in climate mitigation measures (e.g., CER, ASOPEZ) and the international beneficiaries (e.g., CB-VCM and VW/Ford) who want to offset their emissions occur naturally as an outcome of this causal relationship. Required trust (Folke et al. 2005) is then only warranted through the civil society actors as an appropriate intermediary (e.g., EI, NEO). Altogether, the role of civil society actors as an intermediary between other actors in CBEM seems central. In all the examples, civil society actors are among the most active, typically positioned between levels with multilevel and cross-level engagement. They seem crucial in connecting those actors that were isolated before and have access to different resources. Only by pooling those resources can the governance change actually occur. The importance of such intermediaries has also been the focus of recent research (e.g., Bosselmann and Lund 2013, Schomers et al. 2015, Schröter et al. 2015).

\section{Why did new actors emerge?}

Because governance change never occurs in an institution-free domain (Vatn and Vedeld 2012), negotiation of adapted or new roles must always occur with respect to the existing actors. Although some essential roles regarding the new governance approach can be assumed by these actors, other roles cannot. In the first case, the options include up- and down-skilling of existing actors, or even merging of some actors; in the second case, new actors must be established (Van der Heijden 2011).

In all four case studies, new actors were created (e.g., AMOMAR, PCOU, SCAR, and CORAC/COLAP), which occurred to enable cross-scale interactions for decision making. For instance, AMOMAR was founded to link the community via PCOU (also newly created) to the PEIC. CORAC and COLAP were established for the same reason, i.e., to bridge the gap between the local community and regional actors (e.g., ACOSA). In Tocantins, SCAR was founded as a private spin-off of the NGO involved for independent credit appraisal and verification, linking the credit producers (CER) at the local level to international credit buyers (CB-VCM). All new actors were created intentionally to allow for cross-level interactions, and their roles were agreed upon by means of negotiation (see Vatn and Vedeld 2012).

\section{What were the motives of the different actors to be engaged in community-based environmental management?}

Because of its twin objectives, reconciliation of ecological and socioeconomic interests is inherently part of CBEM. When looking at the different societal spheres, public actors' interest mostly involves providing public goods, and benefit for the involved state actors (e.g., PEIC, EPOL/PGUA, ACOSA, SINAC) is improved conservation. Market actors' interest is for profit (e.g., FARM, DAIR, CER, SCAR) but can nonetheless involve environmental and social objectives (e.g., corporate social responsibility). Their benefit arises from generating income from specific services (e.g., credit verification, milk processing); if they do it in a more environmentally sustainable manner (e.g., CER, FARM), they also can improve their image. Civil society actors' interest is not for profit but for the common good (e.g., AMOMAR, GPVoisin, EI, and NEO). Their benefits are related to achieving their respective missions, which, in all cases, include combinations of environmental and socioeconomic aims. Thus, although there are multiple interests that coexist, every actor receives something out of the CBEM arrangement that makes the engagement worthwhile.

Among levels, at the local community level, there is a strong link between the conditions of environmental resources and local livelihoods. Consequently, environmental improvements directly translate into livelihood improvements for local communities (e. g., AMOMAR, FARM, CER, ASOPEZ), which strongly motivates them to engage in CBEM (V. Nath, unpublished manuscript: http://www.cddc.vt.edu/knownet/lse-cbd.pdf). At the national level, law making and rural planning likewise involve conservation and rural development. However, for developing and emerging economies, there is typically a gap between de jure and de facto rules (Young 2002). Thus, through cooperation with the regional and local actors, this gap can be narrowed substantially (e.g., Marujá community helps PEIC in monitoring; by switching its energy source, CER falls into compliance with existing laws for native forest protection). At the international level, the motivation to become engaged in CBEM activities results from functional interdependencies because the international community is a general beneficiary of every local initiative for biodiversity and climate protection. Some encouragement might also emanate from international agreements such as CITES (Convention on International Trade 
in Endangered Species of Wild Fauna and Flora), the Kyoto protocol, or COP (Conference of the Parties).

When examining how the entire process of governance change began, in all case studies, CBEM was initialized from the bottomup, either by the community itself (AMOMAR) or by locally active civil society actors (GPVoisin, EI, and NEO). This process stands in stark contrast to many reported unsuccessful CBEM examples in which the process was initiated from the top-down by government mandate or by international NGOs or donor agencies (Blaikie 2006). Thus, it is important to note that, in all cases, there was no imposed reorganization from the top-level downward. Another important aspect relates to the fact that, in most cases, the process did not begin as a project with a given runtime, but as a long-term endeavor. Thus, the process is carried forward by the local communities, driven by the high priority to sustain the natural resources they depend on for their livelihoods (Young 2002).

\section{How were problems and conflicts addressed?}

In all cases, governance change finally led to a working CBEM solution. However, the change process took some time and was not without conflict or failure. For instance, in Marujá, the aim of PEIC was not community development but conservation; moreover, relocation of communities was planned. Only after persistent negotiation could AMOMAR finally communicate the advantages for both sides if the community stayed on, which required nothing less than a paradigm shift on behalf of PEIC because allowing communities to stay in the park violated existing laws. In Santa Catarina, winning over farmers was hard at first and only became possible because of students' voluntary engagement in GPVoisin. In addition, only through long-time local engagement in Osa could NEO earn the trust of the communities. In Tocantins, the first attempts by EI to create carbon credits directly from reforestation projects failed and only became successful after adapting the basic idea for the ceramic industry.

In addition, after the CBEM solutions were worked out, a forum for conflict resolution was required (Ostrom 1990). In Marujá, AMOMAR serves as the forum for local conflict resolution, and decisions are made by majority vote. At the regional level, for discussing exceptions from the rules laid out in the management plan (e.g., enlargement or renovation of existing houses), PCOU is used, and rules in the management plan can be adapted and renegotiated every five years. In Santa Catarina, during the transition phase to the Voisin system, farmers receive counseling from GPVoisin. Additionally, farmers who already have the system in place organize field days that serve as a forum for colearning, and farmer-to-farmer advice can be given to colleagues who have difficulties in adjusting the system to their needs. In Tocantins, indicators for measuring socioeconomic, technical, and environmental improvements in the ceramic factories as a basis for the additional premium to the carbon credits are self-defined. It is also the community that measures the improvements that are then verified by SCAR as a third party at the national level. In Osa, as in Marujá, two councils (CORAC/ COLAP) at the local and regional level were created for disputing problems and to enable decision making. Thus, in all four cases, there are specific infrastructures for addressing problems and conflicts at different levels, and all are accepted by higher level authority (e.g., through PEIC, EPAGRI, ACOSA, or SINAC). There are also examples in which the communities improved their performance in the light of experience (Vatn and Vedeld 2012). For instance, in Marujá, for electing the board of AMOMAR, a system with two competing teams was first used in which members originated from two different family clans. Because that process led to the problem that the elected team would favor family members in certain decisions, the system was changed to feature mixed family teams with the objective of preventing concentration of power within certain groups (Kellert et al. 2000, Blaikie 2006).

\section{How will the developed community-based environmental} management approaches develop into the future?

Robustness and durability are other aspects of CBEM (Young 2002), but changing the frame conditions is likely to affect the CBEM solutions in all four case studies in the future. In Marujá, for instance, concerns were voiced in the interviews that younger people in the community might opt out of the current arrangement because they tend to favor modern rather than traditional lifestyles. Thus, it is unclear whether the approach will continue over the long run. For the other three cases, there are plans for improvements or transfer. In Santa Catarina, the development of a payment for ecosystem services for farmers who would receive a payment for implementing native tree clusters for reconnecting fragmented forest habitat is envisaged. Thus far, tree clusters are often implemented with eucalyptus trees that have little habitat value but earn additional income for the farmer from the fast-growing timber. Consequently, the approach would develop into another hybrid that includes a market-based approach. In Tocantins, activities are under way to generate Socialcarbon ${ }^{\circledR}$ credits to improve grassland management on cattle ranches and avoid emissions that result from converting native forest into additional pastureland. In Osa, the CBEM and payment for ecosystem services approach for mangrove protection and reforestation is planned to be transferred to other communities on the Nicoya peninsula. For all cases that entail a payment for ecosystem services approach (Tocantins, Osa, and possibly Santa Catarina in the future), success then depends on the interest of potential buyers in the generated credits. Altogether, adaptability to changing environmental and social conditions will determine in what way the CBEM approaches continue into the future.

Can the developed community-based environmental management approaches be transferred to other communities?

All presented approaches may potentially be transferred to other settings, not only in Latin America but elsewhere. For some cases (e.g., Tocantins, Osa), transfers have already been undertaken or are under way. With regard to the exact makeup of the actors' networks, we expect that they cannot be copied one to one but rather must evolve in a context-dependent manner. Contextuality is central because experience shows that arrangements with an excellent fit for one context can fail for another (Vatn and Vedeld 2012). The basic challenge always will be to make the arrangement fit the dynamics and complexities of the new context based on the existing actors (Vatn and Vedeld 2012). Who eventually assumes the different roles will be an outcome of the negotiation process among actors during the governance change. Negotiating roles will likely involve up- or down-skilling of certain actors, but might also entail creation of new ones (Van der Heijden 2011). 
Despite this context dependency, however, some roles might stick with the same type of actor, which might be particularly true for civil society actors, who were often found to serve as intermediaries between other actors. This role certainly can be related to the characteristics of the civil society sector, which is understood as independent from the other two spheres and has no official mandates or predefined agendas. This characteristic makes a civil society actor a suitable partner for both local community actors and state actors at either the state or federal level (Simsa 2001). Against the backdrop of the analyzed cases, facilitating factors for the transfer process include the following: mutual acknowledgement of the problem, a positive attitude toward change, leadership, trust, access to sufficient resources (e. g., knowledge, funding), collaborative planning and learning, and the necessary authority to implement the planned changes (Mitton et al. 2007).

\section{Implications for future research}

Overall, CBEM solutions represent complex situations in which roles of single actors are not predefined but are the outcome of a context-dependent negotiation. Thus, in terms of future research, long-term studies would be extremely valuable to determine how resilient CBEM approaches are over time and how they adapt in response to changing conditions, possibly changing from one hybrid to another. In some cases, changing conditions might also render a previously working CBEM approach unsuitable.

Because the CBEM cases analyzed here only represent single examples of each of the possible governance hybrids in CBEM, the analysis of additional cases per hybrid for cross-comparison would be helpful to verify observations and patterns, particularly in regard to the role of civil society actors. It would also be worthwhile to add social network analysis to the research design to obtain more information on the type and quality of actor relations, e.g., the flow of knowledge or financial resources within the actors' network, perceived power relations of single actors, and actors' motivations, particularly with respect to the role of civil society actors.

Another way forward may be to study in more detail how certain governance approaches (i.e., hierarchies, markets, and community management) shape motivations. For instance, markets address the individual interest of actors, whereas community management typically attempts to combine individual and common interests to facilitate collective action. Thus, favoring one approach over the other will influence what type of motivation will be activated and dominate.

\section{CONCLUSIONS}

We introduced four CBEM cases for MLG analysis. The analysis combined the virtues of in-depth case-based and more general cross-case research, with cases varying greatly in terms of the composition of actors and types of arrangements. Based on the analyzed cases, we emphasize the following points in view of how MLG can strengthen CBEM. First, looking for the best or most appropriate level of social organization (local to international) at which to address a particular local problem does not help to explain CBEM outcomes. Moreover, the success of CBEM is defined by the sum of the horizontal and vertical interactions of the involved actors. Only the cooperation of actors from different societal spheres within and across levels ensures accessibility to required resources and effective implementation on the ground. Thus, looking at the MLG arrangement adds to the understanding of how single CBEM approaches actually work in terms of who is involved and in what roles. Second, civil society actors in particular seem to be critical actors in CBEM because they frequently function as initiators of governance change and bridging structures connecting actors across levels as intermediaries positioned between levels. In this manner, they connect local actors who provide the necessary place-based knowledge with national or international actors who provide other important resources such as professional knowledge or external funding. Third, new actors emerged mostly to enable cross-scale interaction for improved decision making, i.e., to transform a system of isolated decision making into one of mutual decision making connecting all levels involved. New actors were created intentionally, and their roles were negotiated willfully among the actors. Fourth, despite the divergent interests of actors, CBEM solutions were able to provide benefits to all the involved actors. Thereby, all CBEM approaches were developed bottomup, either through community actors or locally active civil society initiatives. Fifth, it seems indispensable that procedures to address problems or mitigate conflicts among actors at different levels must be established. In most cases, these procedures are closely linked to the procedures that are used for mutual decision making. Sixth, in terms of transferability, MLG analysis in environmental governance such as CBEM should be informed by the recognition that both vertical and horizontal differentiations in the cooperation of actors are likely to characterize complex solutions that work for a specific context and that cannot be transferred exactly to another context. It adds further to this complexity that CBEM arrangements are subject to change over time. Because we included only one example per possible governance hybrid in CBEM, more research is required for better cross-case comparison, particularly with regard to the particular role of civil society actors.

Responses to this article can be read online at: http://www.ecologyandsociety.org/issues/responses. $\mathrm{php} / 8475$

\section{Acknowledgments:}

This paper is based on research conducted in the CiVi.net project funded under contract number 282750 within the 7th Framework Programme of the European Commission. We thank all involved stakeholders in the different case studies for participating in the project and for sharing their valuable knowledge and experience with us. We also thank all CiVi.net project partners for their support during the case study visits and for their fruitful cooperation in the project. Further thanks go to two anonymous reviewers and the subject editor, who helped us to improve an earlier draft of the paper through their valuable feedback and comments. A draft version of this paper was presented at the ESP conference 2014 on "Local action for the common good" in San José, Costa Rica. 


\section{LITERATURE CITED}

Agrawal, A., and C. C. Gibson. 1999. Enchantment and disenchantment: the role of community in natural resource conservation. World Development 27(4):629-649. http://dx.doi. org/10.1016/S0305-750X(98)00161-2

Armitage, D. 2007. Governance and the commons in a multi-level world. International Journal of the Commons 2(1):7-32. http://dx. doi.org/10.18352/ijc. 28

Armitage, D., F. Berkes, and N. Doubleday. 2007. Adaptive comanagement: collaboration, learning, and multi-level governance. UBC Press, Vancouver, Canada.

Bache, I., and M. Flinders, editors. 2004. Multi-level governance. Oxford University Press, Oxford, UK.

Berkes, F. 2006. From community-based resource management to complex systems. Ecology and Society 11(1):45. [online] URL: http://www.ecologyandsociety.org/vol11/iss1/art45/

Berkes, F., and C. S. Seixas. 2004. Lessons from community selforganization and cross-scale linkages in four Equator Initiative projects. Centre for Community-based Resource Management, University of Manitoba, Winnipeg, Canada. [online] URL: https://umanitoba.ca/institutes/natural_resources/pdf/Lessons $\% 20$ from $\%$ 20Community $\% 20$ Self-Organization $\% 20$ and $\% 20$ Cross-Scale $\%$

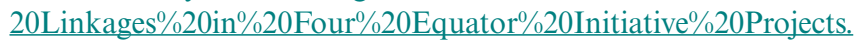
pdf

Blaikie, P. 2006. Is small really beautiful? Community-based natural resource management in Malawi and Botswana. World Development 34(11):1942-1957. http://dx.doi.org/10.1016/j. worlddev.2005.11.023

Bosselmann, A. S., and J. F. Lund. 2013. Do intermediary institutions promote inclusiveness in PES programs? The case of Costa Rica. Geoforum 49:50-60. http://dx.doi.org/10.1016/j. geoforum.2013.05.009

Carlsson, L., and F. Berkes. 2005. Co-management: concepts and methodological implications. Journal of Environmental Management 75(1):65-76. http://dx.doi.org/10.1016/j.jenvman.2004.11.008

Cash, D. W., W. N. Adger, F. Berkes, P. Garden, L. Lebel, P. Olsson, L. Pritchard, and O. Young. 2006. Scale and cross-scale dynamics: governance and information in a multilevel world. Ecology and Society 11(2):8. [online] URL: http://www.ecologyandsociety. org/vol11/iss $2 /$ art $8 /$

Chambers, R., A. Pacey, and L. A. Thrupp, editors. 1989. Farmer first: farmer innovation and agricultural research. IT Publications, London, UK. [online] URL: http://www.future-agricultures.org/ farmerfirst/farmer first.html

Cox, M., G. Arnold, and S. Villamayor Tomás. 2010. A review of design principles for community-based natural resource management. Ecology and Society 15(4):38. [online] URL: http:// www.ecologyandsociety.org/vol15/iss4/art38/

Diekmann, A. 2001. Empirische sozialforschung: grundlagen, methoden, anwendungen. Rowohlt, Reinbek, Germany.

Dietz, T., E. Ostrom, and P. C. Stern. 2003. The struggle to govern the commons. Science 302:1907-1912. http://dx.doi.org/10.1126/ $\underline{\text { science. } 1091015}$
Ernstson, H., S. Barthel, E. Andersson, and S. T. Borgström. 2010. Scale-crossing brokers and network governance of urban ecosystem services: the case of Stockholm. Ecology and Society 15(4):28. [online] URL: http://www.ecologyandsociety.org/vol15/ iss $4 / \operatorname{art} 281$

Flick, U. 2004. Triangulation: eine einführung. VS Verlag für Sozialwissenschaften, Wiesbaden, Germany.

Folke, C., T. Hahn, P. Olsson, and J. Norberg. 2005. Adaptive governance of social-ecological systems. Annual Review of Environment and Resources 30:441-473. http://dx.doi.org/10.1146/ annurev.energy.30.050504.144511

Freeman, R. E. 1984. Strategic management: a stakeholder approach. Pitman, Boston, Massachusetts, USA. http://dx.doi. org/10.1017/cbo9781139192675

Gruber, J. S. 2010. Key principles of community-based natural resource management: a synthesis and interpretation of identified effective approaches for managing the commons. Environmental Management 45(1):52-66. http://dx.doi.org/10.1007/s00267-008-9235$\mathrm{y}$

Kellert, S. R., J. N. Mehta, S. A. Ebbin, and L. L. Lichtenfeld. 2000. Community natural resource management: promise, rhetoric, and reality. Society and Natural Resources 13(8):705-715. http://dx.doi.org/10.1080/089419200750035575

Kluvánková-Oravská, T., V. Chobotová, I. Banaszak, L. Slavikova, and S. Trifunovova. 2009. From government to governance for biodiversity: the perspective of central and Eastern European transition countries. Environmental Policy and Governance 19(3):186-196. http://dx.doi.org/10.1002/eet.508

Lamnek, S., and C. Krell. 2010. Qualitative sozialforschung: lehrbuch. Beltz, Weinheim, Germany.

Liu, J., H. Qu, D. Huang, G. Chen, X. Yue, X. Zhao, and Z. Liang. 2014. The role of social capital in encouraging residents' proenvironmental behaviors in community-based ecotourism. Tourism Management 41:190-201. http://dx.doi.org/10.1016/j. tourman.2013.08.016

Lunch, N., and C. Lunch. 2006. Insights into participatory video: a handbook for the field. InsightShare, Oxford, UK. [online] URL: http://www.insightshare.org/resources/pv-handbook.html

Luthe, T., and R. Wyss. 2016. Resilience to climate change in a cross-scale tourism governance context: a combined quantitativequalitative network analysis. Ecology and Society 21(1):27. http:// dx.doi.org/10.5751/es-08234-210127

Marks, G., and L. Hooghe. 2004. Contrasting visions of multilevel governance. Pages 15-30 in I. Bache and M. Flinders, editors. Multi-level governance. Oxford University Press, Oxford, UK. http://dx.doi.org/10.1093/0199259259.003.0002

Matzdorf, B., C. Biedermann, C. Meyer, K. Nicolaus, C. Sattler, and S. Schomers. 2014. Paying for green? Payments for ecosystem services in practice: successful examples of PES from Germany, the United Kingdom and the United States. Oekom, Munich, Germany. [online] URL: http://www.civiland-zalf.org/download/ PayingforGreen_PESinpractice.pdf 
Mayring, P. 2008. Qualitative inhaltsanalyse: grundlagen und techniken. Beltz, Weinheim, Germany.

Mitton, C., C. E. Adair, E. McKenzie, S. B. Patten, and B. Waye Perry. 2007. Knowledge transfer and exchange: review and synthesis of the literature. Milbank Quarterly 85(4):729-768. http://dx.doi.org/10.1111/j.1468-0009.2007.00506.x

Newig, J., and O. Fritsch. 2009. Environmental governance: participatory, multi-level - and effective? Environmental Policy and Governance 19(3):197-214. http://dx.doi.org/10.1002/eet.509

Ostrom, E. 1990. Governing the commons: the evolution of institutions for collective action. Cambridge University Press, Cambridge, UK.

Paavola, J. 2008. Explaining multi-level environmental governance. Sustainability Research Institute Papers 10. Sustainability Research Institute, University of Leeds, Leeds, UK. [online] URL: https:/www.see.leeds.ac.uk/fileadmin/Documents/research/ sri/workingpapers/SRIPs-10 01.pdf

Pahl-Wostl, C. 2009. A conceptual framework for analysing adaptive capacity and multi-level learning processes in resource governance regimes. Global Environmental Change 19(3):354-365. http://dx.doi.org/10.1016/j.gloenvcha.2009.06.001

Pellizzoni, L. 2003. Uncertainty and participatory democracy. Environmental Values 12(2):195-224. http://dx.doi. org/10.3197/096327103129341298

Pritchard, L. Jr., and S. E. Sanderson. 2002. The dynamics of political discourse in seeking sustainability. Pages 147-169 in L. H. Gunderson and C. S. Holling, editors. Panarchy: understanding transformations in human and natural systems. Island Press, Washington D.C., USA.

Sattler, C., and B. Matzdorf. 2013. PES in a nutshell: from definitions and origins to PES in practice - approaches, design process and innovative aspects. Ecosystem Services 6:2-11. http:// dx.doi.org/10.1016/j.ecoser.2013.09.009

Scholz, R. W., and O. Tietje. 2002. Embedded case study methods: integrating quantitative and qualitative knowledge. Sage Publications, Thousand Oaks, California, USA. http://dx.doi. org/10.4135/9781412984027

Schomers, S., C. Sattler, and B. Matzdorf. 2015. An analytical framework for assessing the potential of intermediaries to improve the performance of payments for ecosystem services. Land Use Policy 42:58-70. http://dx.doi.org/10.1016/j. landusepol.2014.06.025

Schreurs, M. A. 2010. Multi-level governance and global climate change in East Asia. Asian Economic Policy Review 5(1):88-105. http://dx.doi.org/10.1111/j.1748-3131.2010.01150.x

Schröter, B., B. Matzdorf, C. Sattler, and G. Garcia Alarcon. 2015. Intermediaries to foster the implementation of innovative land management practice for ecosystem service provision - a new role for researchers. Ecosystem Services 16:192-200. http://dx.doi. org/10.1016/j.ecoser.2015.10.007

Schröter, B., K. Sessin-Dilascio, C. Meyer, B. Matzdorf, C. Sattler, A. Meyer, G. Giersch, C. Jericó-Daminello, and L. Wortmann. 2014. Multi-level governance through adaptive co-management: conflict resolution in a Brazilian state park. Ecological Processes 3:6. http://dx.doi.org/10.1186/2192-1709-3-6

Seixas, C. S., and F. Berkes. 2010. Community-based enterprises: the significance of partnerships and institutional linkages. International Journal of the Commons 4(1):183-212. http://dx.doi. org/10.18352/ijc.133

Simsa, R. 2001. Die Zivilgesellschaft als Hoffnungsträger zur Lösung gesellschaftlicher Probleme? Zwischen Demokratisierung und Instrumentalisierung gesellschaftlichen Engagements. Pages 23-40 in Institut für Sozialarbeit und Sozialpädagogik e. V., editor. Europäische Integration als Herausforderung: Rolle und Reform der sozialen Dienste in Europa. Institut für Sozialarbeit und Sozialpädagogik, Frankfurt, Germany. [online] URL: http:// www.soziale-dienste-in-europa.de/Anlage16341/

Europaeische_Integration_als_Herausforderung.pdf

Stern, P. C. 2005. Deliberative methods for understanding environmental systems. BioScience 55(11):976-982. http://dx.doi. org/10.1641/0006-3568(2005)055[0976:DMFUES]2.0.CO;2

Van der Heijden, J. 2011. Friends, enemies, or strangers? On relationships between public and private sector service providers in hybrid forms of governance. Law and Policy 33(3):367-390. http://dx.doi.org/10.1111/j.1467-9930.2011.00344.x

Vatn, A. 2005. Institutions and the environment. Edgar Elgar, Cheltenham, UK.

Vatn, A. 2010. An institutional analysis of payments for environmental services. Ecological Economics 69(6):1245-1252. http://dx.doi.org/10.1016/j.ecolecon.2009.11.018

Vatn, A., and P. Vedeld. 2012. Fit, interplay, and scale: a diagnosis. Ecology and Society 17(4):12. http://dx.doi.org/10.5751/ es-05022-170412

Young, O. R. 2002. The institutional dimensions of environmental change: fit, interplay, and scale. MIT Press, Cambridge, Massachusetts, USA. 